\title{
Study on Effect of EAFD Particulate Reinforcement in AA7075 Aluminum Matrix Composites
}

\author{
Elizeth Oliveira Alves ${ }^{a}$, Daniel Ricardo Araújo Amaro ${ }^{a}$,Enéas Carlos de Oliveira Silva ${ }^{a}$, Oscar \\ Olimpio de Araújo Filho ${ }^{a}$, Kleber Gonçalves Bezerra Alves ${ }^{a} *$
}

\author{
${ }^{a}$ Departamento de Engenharia Mecânica, Universidade Federal de Pernambuco, Av. da Arquitetura s/n, \\ 50670-901, Recife, PE, Brasil
}

Received: August 30, 2017; Revised: July 07, 2018; Accepted: August 18, 2018

\begin{abstract}
Eletric arc furnace dust is dangerous solid waste that is generated in steel manufacturing processes. The utilization of the dust from these industries avoids disposing it into industrial waste landfills and saves costs. In this study, an attempt has been made to fabricate aluminum matrix composites reinforced with EAFD particulate, throught the conventional powder metallurgy technique. Al-5\%EAFD proposed was then compared to the AA7075 alloy, manufactured under the same conditions. According to the results obtained, the addition of EAFD into aluminum matrix resulted in increased microhardness values and had significant contributuion to improve Storage modulus compared with the base metal. The reinforcement particle was uniformly dispersed into the matrix and intermetallic phases were not observed in the content of waste blended into the composite.
\end{abstract}

Keywords: $E A F D$, aluminum composite, powder metallurgy.

\section{Introduction}

Steel mills utilize primarily five differents inputs groups in their manufacturing processes: raw materials, air, water, fuel and power; however, these supplies are responsable for generating large quantities of several types of solid waste. It is estimated that during steel production between 2 and 4 tonnes of waste, as sludge, dust and slag are generated ${ }^{1}$.

Eletric arc furnace dust (EAFD) is one of by-products of steelmaking industry resulting from the melting of scrap and from steel refining. It is formed through the conversion of vapours into dust, by means of agglomeration, and physical and chemical transformations. The steel dust formed is collected by a system that captures gases and particulate matter. The type of scrap metal melted inside the electric arc furnace (EAF) determines the chemical composition of the dust, which is defined as a rich material in ferrous or nonferrous metal. EAFD is composed of iron and zinc oxide, which is volatilized, and also calcium, chromium, magnesium, sílica and, other toxic compounds as lead and cadmium $^{2,3,4,5}$.

The formation process of EAFD occurs in two stages: first, the emission of dust "precursors", second, the conversion of these precursors into dust by agglomeration and physico-chemical transformations. The different types of particles are formed by five emission mechanisms of dust precursors, mainly projection of fine droplets by bursting of $\mathrm{CO}$ bubbles. Studies confirm the existence of two fine particle populations: submicronic particles of zincite coming from the vaporization of the liquid steel, and film drops;

*e-mail: kleber.gbalves@ufpe.br homogeneous and heterogeneous spherical particles, whose composition corresponds either to the slag or to the steel bath with an enrichment in zinc. The size of large particles vary between 20 and $500 \mu \mathrm{m}$, with irregular shapes, and come from the direct fly-off of solid particles during the introduction of powder materials into the $\mathrm{EAF}^{6,7}$.

Zinc is generally found as franklinite, ferrite particles rich in zinc (spinel $-\mathrm{ZnFe}_{2} \mathrm{O}_{4}$ ), and as calcium ferrite (spinel- $\mathrm{Ca} \mathrm{Fe}_{2} \mathrm{O}_{4}$ ), or ferrites with isomorphously replaced metals $\left(\mathrm{Zn}_{\mathrm{x}}, \mathrm{Me}_{\mathrm{y}}\right) \mathrm{Fe}_{2} \mathrm{O}_{4}$, where $\mathrm{Me}=\mathrm{Mn}, \mathrm{Co}, \mathrm{Ni}, \mathrm{Cr}$, etc., and zincite $(\mathrm{ZnO})$. With the exception of franklinite, iron is mostly found in the magnetite phase $\left(\mathrm{Fe}_{3} \mathrm{O}_{4}\right)$. In addition to the oxides mentioned, the EAFD includes in its compostion: carbon (coke), calcite $\left(\mathrm{CaCO}_{3}\right)$, silica $\left(\mathrm{SiO}_{2}\right)$, and aluminum silicate. Depending on its composition and combination of elements, EAFD becomes a byproduct that is difficult to recycle, impeding the development of recovery process of the metal of interest $t^{6,7,8,9}$.

In the steelmaking process in electric arc furnaces, dust formation has been estimated to be between $15-25 \mathrm{~kg}$ of dust per tonne of steel produced. Among the suggested methods for recycling this solid waste, pyrometallurgical processes, as well as its application in the ceramic materials field, have been widely used in industry. However, about $60 \%$ of dust produced all over the world is still being stored in yards $4,6,10,11,12,13$.

The composition of the EAFD is extremely variable and influenced by type of steel manufactured, nature and quantity of scrap and alloy aditions, which make up part of burden. In addition to factors related to raw materials, operational factors also affect its composition, such as the type of furnace, operating cycle, and gas cleaning system efficiency ${ }^{14}$. 
Powder Metallurgy (PM) is an appropriate method for metal matrix composite processing due to its simple processing and ample applications in different fields, such as transportation, the aerospace and infrastructure ${ }^{15,16}$. PM allows for recycling of solid waste in its solid state, transforming it into useful products through the reduction of metal oxides present in the steelmaking dusts and in its composition during sintering ${ }^{17}$.

Many solutions have been proposed for the technical utilization of the EAFD in several fields. The main approaches for recycling the waste are related to pyrometallurgical process, by agglomeration of dust and briquette manufacture to recovery of iron contained in the EAFD ${ }^{4}$. Havlik et al. ${ }^{7}$ study efficiency of recovery of zinc with sulfuric acid as the leaching agent. Among the approaches, the addition of EAFD into ceramic materials are most commonly seen ${ }^{10,18,19}$. Stathopoulos et al. ${ }^{11}$ investigated the stabilization of $\mathrm{Zn}, \mathrm{Pb}$ and $\mathrm{Cd}$ into structural ceramics containing $2.5 \%$ and $5 \%$ wt. of EAFD.

The application of EAFD as reinforcement in aluminum matrix composites (AMC) has been a technological and economic alternative when compared to other reinforcements traditionally applied. In this study, in order to assess the influence of EAFD on the mechanical properties of the AMC, $5 \%$ of waste was embedded into the AA 7075 alloy, and later hardness and morphological behaviour were examined.

\section{Materials and Methods}

This research project was carried out in three stages: EAFD characterization, composite preparation, testing and carachterization of composite manufactured. The AA7075 was blended to content of 5\% in EAFD weight (wt.\%), which had particle size smaller than $53 \mu \mathrm{m}$, and $2 \mathrm{wt} . \%$ stearic acid $\left(\mathrm{C}_{18} \mathrm{H}_{36} \mathrm{O}_{2}\right)$ of the total weight of the sample. Percentage of waste applied was based in blends that have been mentioned in previous studies ${ }^{20,21,22}$. The AA7075 alloy used was produced by ALCOA and EAFD was supplied by a steel mini-mill located in northeast Brazil, originating from smelting of carbon steel scrap.

\subsection{Powders characterization}

Initially EAFD was separated into 4 size ranges, and only the size range smaller than $53 \mu \mathrm{m}$ was used for this research. The EAFD and the AA7075 alloy were submitted to chemical analysis through X-ray fluorescence (XRF) in a Rigaku ZSX Primus spectrometer. A Bruker D8 advance $\mathrm{X}$-ray diffractometer (XRD), using a $\mathrm{CuK} \alpha(\lambda=1.5405 \AA)$ was operated to establish the phases present, the measuring range being from 10 to $80^{\circ}(2 \theta)$ using a step size of $0.02^{\circ}$ and a step time of $1 \mathrm{~s}$ per step. For scanning electron microscopy (SEM), the samples were prepared on a graphite support, and micrographs were carried out on the HITACHI TM3000, and a JOEL JSM5900 scanning electron microscope eqquiped with an EDS was also used for detailed study of the microstructural features and qualitative elemental composition of EAFD, and the particle size distribution by laser diffraction was measured by Malvern Mastersizer.

\subsection{Composite preparation}

The AA7075 aluminum alloy powder was used as starting material. EAFD, aluminum alloy, powders (5 wt.\% and average particulate size of $20 \mu \mathrm{m}$ ) and stearic acid (2 wt.\%) were mixed, with a ball to powder weight ratio of 10:1, in isopropyl alcohol in order to prevent oxidation risk and provide effective mixing, reducing cold welding of powders ${ }^{23}$. Other alcohols are commonly used in ball milling to as control agent ${ }^{15,21}$. After mixing, the blend was dried at $150^{\circ} \mathrm{C}$ to remove isopropyl alcohol. Afterwards, they were compacted by uniaxial pressing in a circular (16 mm diameter) metal die at $1500 \mathrm{MPa}$, and the sintering was carried out at a temperature of $500^{\circ} \mathrm{C}$ during 5 hours under nitrogen atmosphere.

\subsection{Characterization and Testing}

The sintered composite morphology was observed by HITACHI TM3000 scanning electron microscope. Vickers microhardness values were determined using a Emcotest Durascan G5 microhardness tester under a load of $200 \mathrm{~g}$ for $15 \mathrm{~s}$, following the ASTM E-384. Young's modulus (E) measurements were perfomed using a Shimadzu Dynamic UltraMicro Hardness tester type DUH-W201S with a Vicker indenter. For each sample at least five indentations on the sample surface were made, with a maximum load of 100 $\mathrm{mN}$, and a hold time at load-unload of $10 \mathrm{~s}$.

Specimens, originally cylindrical, were prepared and cut for DMA tests with a low speed diamond saw into rectangular section $16 \times 4 \times 2 \mathrm{~mm}$ (length $\mathrm{x}$ width $\mathrm{x}$ thickness). These tests were performed in a dynamic mechanical analyzer (DMA 242E Artemis, Netzsch) using a three-point bending. Dynamic mechanical analysis (DMA) tests were performed for frequency of $1 \mathrm{~Hz}$, and using a maximum amplitude of $20 \mu \mathrm{m}$, from room temperature to $390^{\circ} \mathrm{C}$, during the heating phase with $10^{\circ} \mathrm{C} / \mathrm{min}$ rate $^{24,25}$.

\section{Results and Discussion}

Results from chemical analyses of the EAFD are presented in Table 1. The table shows that iron and zinc are the main components of the dust, nearly 32.69 and 26.06 wt.\%. These values are consistent with those observed in wastes generated in the carbon steel manufacturing processes, however, despite of results obtained being within the expected values in the literature, high iron content indicates a great loss of interest elemento in the process. The residue researched also has small amounts of heavy metals, including cadmium and lead. Levels of lead and cadmium remained within the 
Table 1. Chemical analysis of the main elements present in the EAFD and AA7075.

\begin{tabular}{lcccccccccc}
\hline Element & $\mathrm{Zn}$ & $\mathrm{Fe}$ & $\mathrm{Al}$ & $\mathrm{Si}$ & $\mathrm{Mg}$ & $\mathrm{Cu}$ & $\mathrm{Ca}$ & $\mathrm{Cd}$ & $\mathrm{Pb}$ \\
\hline AA7075 & 2.06 & 0.05 & 94.78 & 0.21 & 2.08 & 0.62 & 0.02 & $\mathrm{nd}$ & $\mathrm{nd}$ \\
EAFD & 26.06 & 32.69 & 2.49 & 7.54 & 3.98 & 0.17 & 6.80 & 0.02 & 0.66
\end{tabular}

minimum levels observed in the literature ${ }^{7,8}$, suggesting a good selection of the scrap used in the production process.

Particle size distribution of the examined EAFD is shown in Figure 1. It presents a heterogeneous distribution of particle size and contains two major size fractions: a very fine grained portion $(10 \mathrm{~nm}$ to $7 \mu \mathrm{m})$ and a coarser part (1-120 $\mu \mathrm{m})^{26}$. Most of the EAFD have a volume average diameter of $20.22 \mu \mathrm{m}$. The study found that the median particle size $\left(\mathrm{d}_{50}\right)$ is around $13.87 \mu \mathrm{m}$, and the majority $\left(\mathrm{d}_{90}\right)$ of the particles were below $50.44 \mu \mathrm{m}$. This prevailing fine size distribution favour their application in metallic powders.

Dutra et al. ${ }^{13}$ analyzed a EAFD of a steel plant located in the southeast region of Brazil and found that $15 \%$ of the particles were coarser than $10 \mu \mathrm{m}$, the median particle size being around $0.5 \mu \mathrm{m}$. Sofilic et al. ${ }^{8}$ characterized the dust samples of a Croatian steelmaker consisting of 100-125 $\mu \mathrm{m}$ particles. On the other hand, Omran \& Fabritius ${ }^{2}$ examinated the electric arc furnace dust of carbon steel produced in steel plants from Finland, showing that $90 \%$ of the particles were smaller than $5.42 \mu \mathrm{m}$, the median being $1.63 \mu \mathrm{m}$.

The X-ray diffraction pattern of the as-received EAFD is illustrated in Figure 2. It is a waste of complex mineralogy, in which four major phases were identified: Franklinite $\left(\mathrm{ZnFe}_{2} \mathrm{O}_{4}\right)$, Magnetite $\left(\mathrm{Fe}_{3} \mathrm{O}_{4}\right)$, Zincite $(\mathrm{ZnO})$ and Quartz $\left(\mathrm{SiO}_{2}\right)$, which form the phases for the main elements of its composition. The results reveal that EAFD has other peaks for minority elements, but in insufficient amounts for appropriate detection. Other phases tipically found in the literature ${ }^{2,4,7,8}$ and the peaks overlap can interfere in the identication of phases belonging to the spinel group ${ }^{27}$.

A typical morphology of the EAFD fraction obtained by SEM with EDS analysis of selected particles are presented in Figure 3a. EAFD are composed by irregularly-shaped particles (see arrows in Figure 3a) and smooth spherical (Figure 3b). Similar forms can be observed in literature ${ }^{2,6,11,13}$. EAFD is

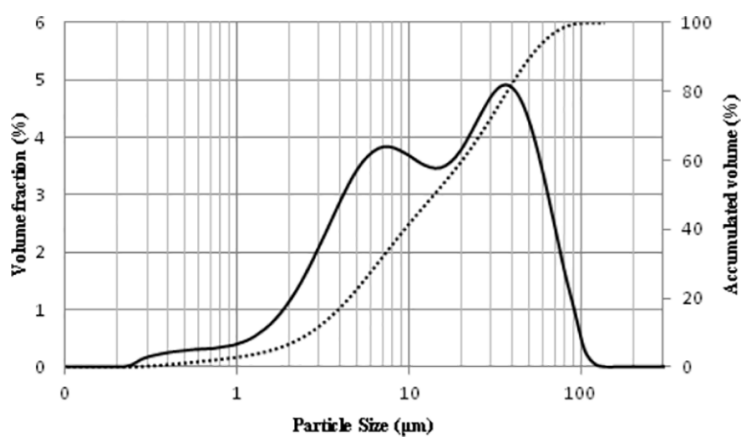

Figure 1. Particle size distribution of the EAFD.

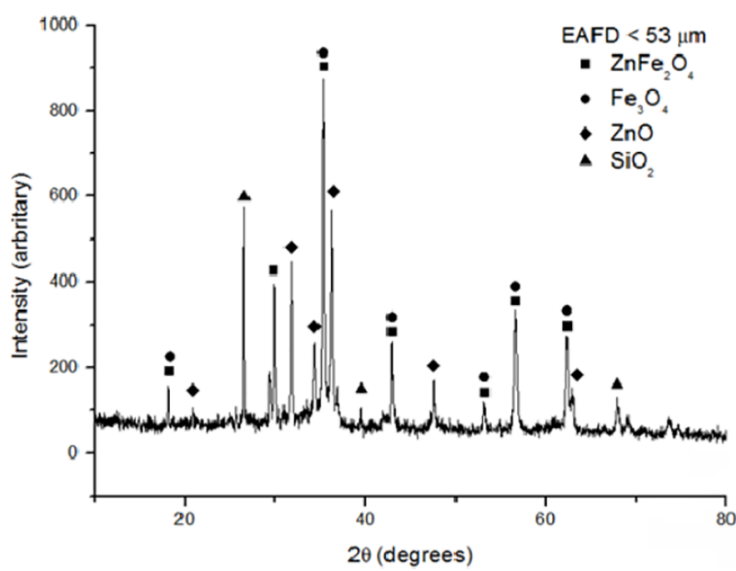

Figure 2. X-ray diffraction difractogram of EAFD.

composed predominantly of spherical particles in the form of agglomerates with varied dimensions (Figure $3 \mathrm{~b}$ ). The predominantely fine particles can differ from each other because of their mineralogy. They come from the projection of liquid droplets, and during the condensation of the vapors of zinc contained in the EAF fumes ${ }^{6}$. EDS analysis (Figure $3 \mathrm{c}$ ) indicates that most of the zinc is associated with the finer dust particles, probably as zincite and ferrites.

SEM micrographs of the Al-5\%EAFD sintered composite are shown in Figure 4. An image with a magnification of $200 \times$ (Figure $4 a$ ) was used to characterize the matrix of composite and an overview of the dispersion of larger and irregular particles of EAFD with a magnification of $500 \times$ (Figure 4b). Spherical shape particle composed of aluminum and zinc agglomerated (Figure 4c). The effect of variation of particles size has not been investigated.

The addition of $5 \mathrm{wt} . \%$ of EAFD resulted in a significant increase in Vicker microhardness (HV) from 85.09 \pm 5.71 to $124.6 \pm 16.92$, in relation to the unreinforced alloy under experimental conditions implemented. The increase in hardness value is caused by the presence of iron and zinc which are in the form of oxides, which have high hardness. Adeosun et $\mathrm{al}^{20}{ }^{20}$ studied the effect of EAFD addition in 2-20 wt.\% content, on the mechanical properties of 6063 aluminum alloy, by casting in a sand mould, which was subsequently cold rolled and heat treated. Flores-Vélez et al. ${ }^{28}$ produced a AMC based on the conventional powder metallurgy technique and obtained the best results of compressive strength and hardness for samples made with $10 \mathrm{wt}$ \% EAFD to about 70 HV. Selvam et al..$^{29}$ applied fly ash in AA6061 aluminum alloy composites obtaining maximum value of $116 \mathrm{HV}$ to $12 \mathrm{wt} . \%$ of waste. Other wastes have been applied as reinforcement 

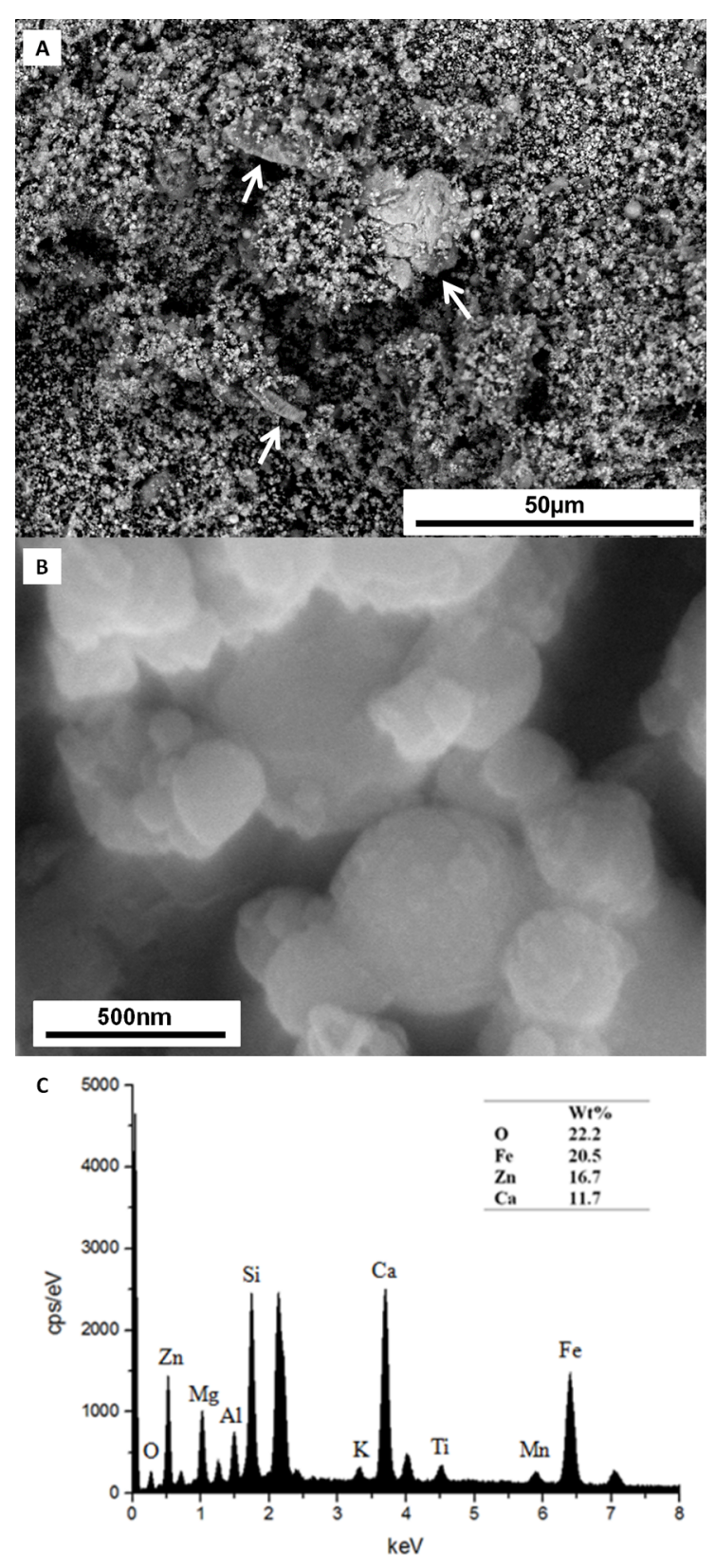

Figure 3. SEM images of EAFD (A), high-magnification SEM images of EAFD (B) and EDS spectra of EAFD particles (C).

aluminum composite, such as granulated $\operatorname{slag}^{28}, \operatorname{red~mud}^{30}$, rice husk ash and graphite ${ }^{31}$. In addition, in the present work it was revealed that EAFD levels higher than 5\% may cause fracture of the composite during the sintering.

Despite the low residue content, the mechanical behavior of the composite differs from that observed in the unreinforced aluminum alloy. The addition of waste in the aluminum matrix has resulted in the increase of mean instrumented Young's modulus (GPa) values, which are distributed widely. For the AA7075 alloy, the Young Modulus (E) are $35.51 \pm 8.50$ and $70.48 \pm 8.36$ for Al-5\%EAFD. These

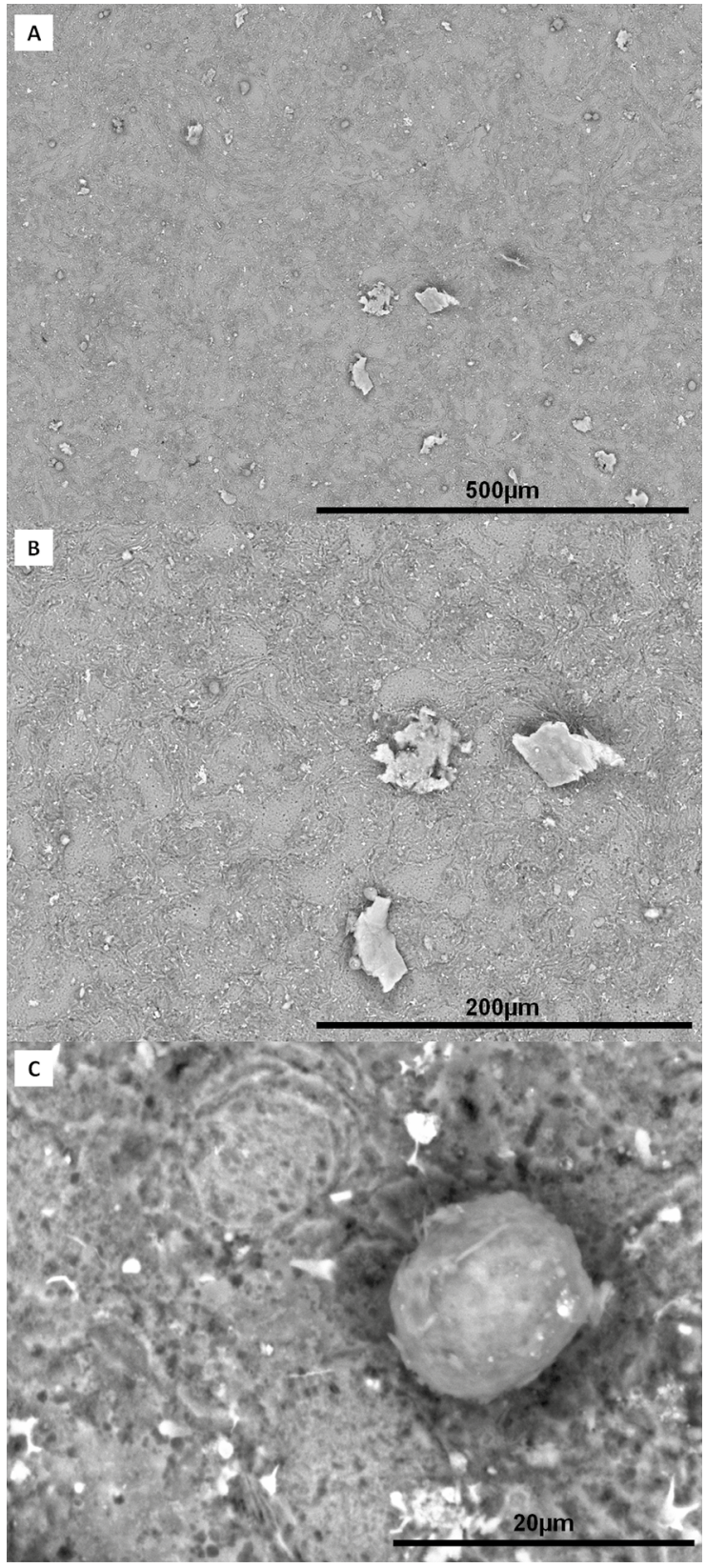

Figure 4. SEM images of Al-5\%EAFD sintered composite with magnification of 200x (A); irregular particles of EAFD with magnification of $500 \mathrm{x}(\mathrm{B})$ and single agglomerated particle in metal matrix $(\mathrm{C})$.

results corroborate with others found in literature ${ }^{32,33}$. Figure 5 shows the Storage Modulus (GPa) data of AA7075 alloy and $\mathrm{Al}-5 \% \mathrm{EAFD}$ composite as a function of temperature at $1 \mathrm{~Hz}$ (quasi-static condition). The addition of EAFD into Al matrix has significant contributuion to improve Young's modulus since the embedded reinforcement particles are stiffer than the matrix ${ }^{34}$. Temperature increase $\left(150-270^{\circ} \mathrm{C}\right)$ leads in a increase in Young's modulus values because foster precipitation hardening ${ }^{34}$. The results obtained are similar with results of Young's modulus determined by UltraMicro 


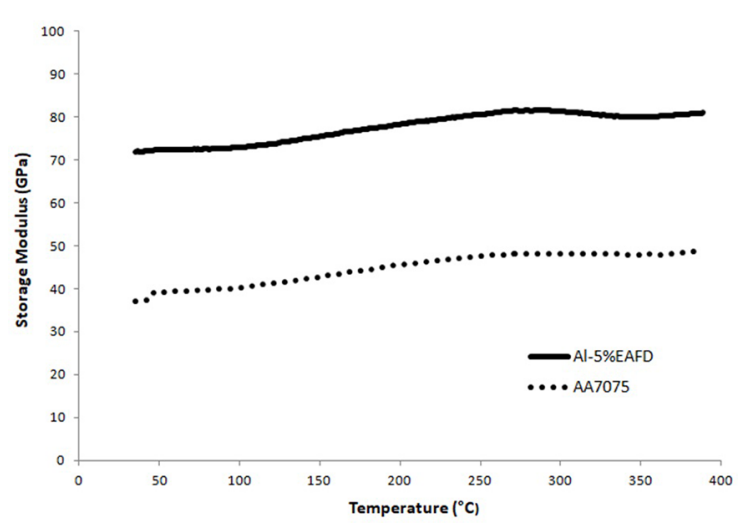

Figure 5. Storage modulus vs. temperature from DMA at frequency of $1 \mathrm{~Hz}$, for Al-5\%EAFD and AA7075 alloy.

Hardness tester at room temperature. The effect of temperature and other reinforcements are reported in literature ${ }^{25,34,35}$.

The XRD patterns for Al-5\%EAFD composite after1hour high-energy ball milling and sintered, and for AA7075 alloy as received, are shown in Figure 6. All the diffraction peaks from the Al matrix are clearly seen. An interesting feature viewed in the $\mathrm{X}$-ray diffractograms is the decrease in the intensity of peaks after composite milling and sintering. This might be due to the reduction in the particle size. Fecht. ${ }^{36}$ reported that the initially sharp diffraction lines are considerably broadened after ball milling due to the refinement of the crystallite size and increase in atomic level strains. Due to the short time of high-energy ball milling assuming that effect don't occur. Formation Al-Fe or Al-FeSi intermetallic phases was not observed in the content of the waste blended in the composite.

\section{Conclusion}

EAFD particles smaller size than $53 \mu \mathrm{m}$ were successfully added to aluminum matrix composites of up to $5 \%$, fabricated through the conventional powder metallurgy technique. Morphology of the EAFD reveal the presence of smooth and irregularly-shaped particles, which can be observed in sintered composite. Addition of EAFD resulted in a significant increase $(46 \%)$ in the hardness value and an increase in instrumented Young's modulus value in relation to the unreinforced alloy, under the experimental conditions implemented. The improvement observed can be due to the oxide particles introduced and the reinforcement particle distribution in the aluminum matrix. The addition of EAFD to Al matrix contributed to the improvement in storage modulus, as well, the temperature increase because foster precipitation hardening between $150-270^{\circ} \mathrm{C}$. The DMA results obtained are similar with results of Young's modulus determined by UltraMicro Hardness tester at room temperature.

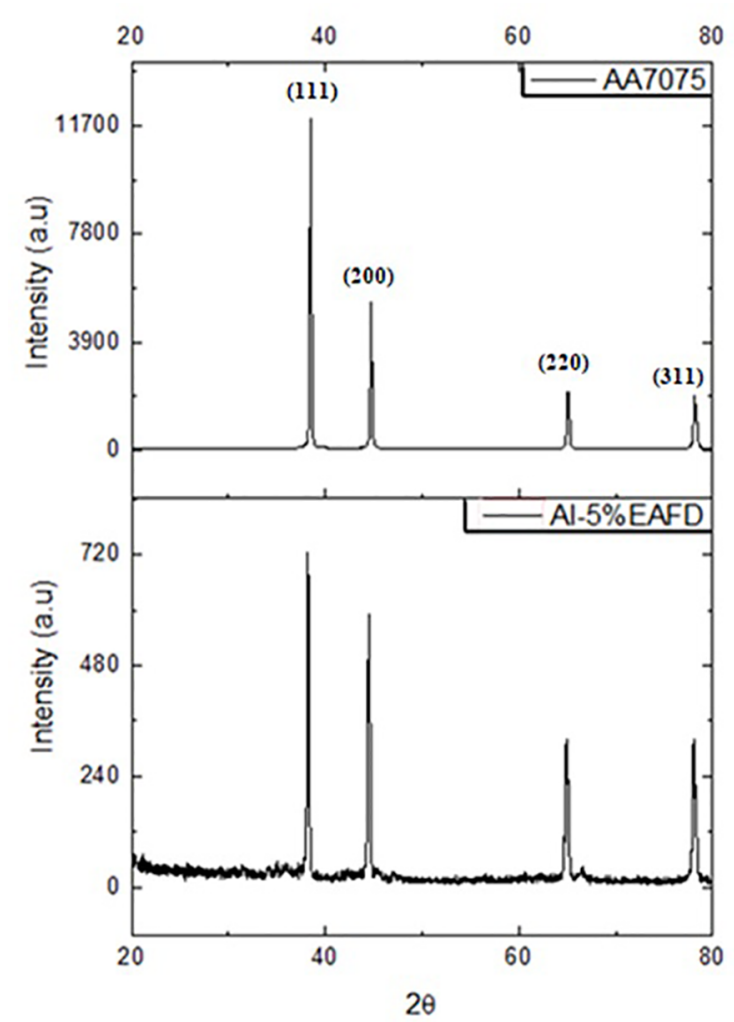

Figure 6. X-ray diffraction difractogram of Al-5\%EAFD sintered composite and AA7075 alloy as received.

\section{Acknowledgements}

The financial support of the Brazilian agencies CNPq (447925/2014-8) and FACEPE (APQ-0916-3.03/14) is gratefully acknowledged. E. O. Alves was recipient of a CAPES graduate fellowship. The authors thank Dr. S. L. Urtiga Filho (UFPE) and Dra. D. G. L. Cavalcante (UFPB) for their generous assistance with DMA and UltraMicro Hardness measurements, respectively.

\section{References}

1. Das B, Prakash S, Reedy PSR, Misra VN. An overview of utilization of slag and sludge from steel industries. Resources, Conservation and Recycling. 2007;50(1):40-57.

2. Omran M, Fabritius T. Effect of steelmaking dust characteristics on suitable recycling process determining: Ferrochrome converter (CRC) and electric arc furnace (EAF) dusts. Powder Technology. 2017;308:47-60.

3. BakkarA. Recycling of electric arc furnace dust through dissolution in deep eutectic ionic liquids and electrowinning. Journal of Hazardous Materials. 2014;280:191-199.

4. Grillo FF, Tenório JAS, de Oliveira JR. Caracterização e adição de poeira de aciaria elétrica em ferro-gusa. Revista Escola de Minas. 2013;66(3):301-307.

5. da Rocha EP, de Castro JA. Characterization and three-dimensional reconstruction of pores of self-reducing pellets done by EAF dust. Materials Research. 2013;17(1):47-55. 
6. Guézennec AG, Huber JC, Patisson F, Sessiecq P, Birat, JP, Ablitzer D. Dust formation in Electric Arc Furnace: Birth of the particles. Powder Technology. 2005;157(1-3):2-11.

7. Havlík T, Vidore Souza B, Bernardes AM, Schneider IAH, Miškufová A. Hydrometallurgical processing of carbon steel EAF dust. Journal of Hazardous Materials. 2006;135(1-3):311-318.

8. Sofilić T, Rastovčan-MiočA, Cerjan-Stefanović S, Novosel-Radović $\mathrm{V}$, Jenko M. Characterization of steel mill electric-arc furnace dust. Journal of Hazardous Materials. 2009;109(1-3):59-70.

9. Xia DK, Pickles CA. Caustic roasting and leaching of electric arc furnace dust. Canadian Metallurgical Quarterly. 1999;38(3):175-186.

10. Ledesma EF, Jiménez JR, Ayuso J, Fernández JM, de Brito J. Experimental study of the mechanical stabilization of electric arc furnace dust using fluid cement mortars. Journal of Hazardous Materials. 2017;326:26-35.

11. Stathopoulos VN, Papandreou A, Kanellopoulou D, Stournaras CJ. Structural ceramics containing electric arc furnace dust. Journal of Hazardous Materials. 2013;262:91-99.

12. de Araujo JA, Schalch V. Recycling of electric arc furnace (EAF) dust for use in steel making process. Journals of Materials Research and Technology. 2014;3(3):274-279.

13. Dutra AJB, Paiva PRP, Tavares LM. Alkaline leaching of zinc from electric arc furnace steel dust. Minerals Engineering. 2006;19(5):478485 .

14. Nyirenda RL. The processing of steelmaking flue-dust: A review. Minerals Engineering. 1991;4(7-11):1003-1025.

15. Mendonza-Duarte JM, Estrada-Guel I, Robles-HernandezFC, CarreñoGallardo C, López-Meléndez C, Martínez-SánchezR. Mechanical and microstructural response of an aluminum nanocomposite reinforced with carbon-based particles. Materials Research. 2016;19(Suppl 1):13-19.

16. Gomes LACM, Travessa DN, González-Carrasco JL, Lieblich M, Cardoso KR. Production of MA956 Alloy Reinforced Aluminum Matrix Composites by Mechanical Alloying. Materials Research. 2015;18(Suppl 2):48-54.

17. Bayraktar E, Katundi D. Development of a new aluminum matrix composite reinforced with iron oxide (Fe3O4). Journal of Achievements in Materials and Manufacturing Engineering. 2010;38(1):7-14.

18. Alsheyab MAT, Khedaywi TS. Effect of electric arc furnace dust (EAFD) on properties of asphalt cement mixture. Resources, Conservation and Recycling. 2013;70:38-43.

19. de Souza CAC, Machado AT, Lima LRPA, Cardoso RJC. Stabilization of electric-arc furnace dust in concrete. Materials Research. 2010;13(4):513-519.

20. Adeosun SO, Akpan EI, Sekunowo OI, Ayoola WA, Balogun SA. Mechanical characteristics of 6063 aluminum-steel dust composite. International Scholarly Research Network-Mechanical Engineering. 2012;2012:461853.

21. Sasaki TT, Ohkubo T, Hono K. Microstructure and mechanical properties of bulk nanocrystalline Al-Fe alloy processed by mechanical alloying and spark plasma sintering. Acta Materialia. 2009;57(12):3529-3538.

22. Krupakara PV, Ravikumar HR. Corrosion characterization of aluminum 6061/Red mud metal matrix composites in sea water. International Journal of Advanced Research in Chemical Science. 2015;2(6):52-55.
23. Gökçe A, Findik F, Kurt AO. Microstructural examination and properties of premixed $\mathrm{Al}-\mathrm{Cu}-\mathrm{Mg}$ powder metallurgy alloy. Materials Characterization. 2011;62(7):730-735.

24. Madeira S, Miranda G, Soares D, Silva FS, Carvalho O. Study on damping capacity and dynamic Young's modulus of aluminium matrix composite reinforced with $\mathrm{SiC}$ particles. Ciência \& Tecnologia dos Materiais. 2017;29(1):e92-e96.

25. Fan G, Li Z, Zhang D. Damping capacity of $\mathrm{BaTiO}_{3} / \mathrm{Al}$ composites fabricated by hot extrusion. Transactions of Nonferrous Metals Society of China. 2012;22(10):2512-2516.

26. Tang H, Wang L, Sun W, Hu Y, Han H, Zhai J. Electric arc furnace dust as magnetic carrier particles for removal of microfine particles from suspensions. Separation and Purification Technology. 2017;176:220-230.

27. Machado JGMS, Brehm FA, Moraes CAM, dos Santos CA, Vilela ACF, da Cunha JBM. Chemical, physical, structural and morphological characterization of the electric arc furnace dust. Journal of Hazardous Materials. 2006;136(3):953-960.

28. Flores-Vélez LM, Chávez J, Hernández L, Domínguez O. Characterization and properties of aluminum composite materials prepared by powder metallurgy techniques using ceramic solid wastes. Materials and Manufacturing Processes. 2001;16(1):116.

29. Selvam JDR, Smart DSR, Dinaharan I. Microstructure and some mechanical properties of fly ash particulate reinforced AA6061 aluminum alloy composites prepared by compocasting. Materials \& Design. 2013;49:28-34.

30. Rajesh S, Rajakarunakaran S, Suthakarapandian R, Pitchipoo P. MOORA-Based Tribological Studies on Red Mud Reinforced Aluminum Metal Matrix Composites. Advances in Tribology. 2013;2013:213914.

31. Alaneme KK, Sanusi KO. Microstructural characteristics, mechanical and wear behavior of aluminium matrix hybrid composites reinforced with alumina, rice husk ash and graphite. Engineering Science and Technology, an International Journal. 2015;18(3):416-422.

32. Antunes JM, Cavaleiro A, Menezes LF, Simões MI, Fernandes JV. Ultra-microhardness testing procedure with Vickers indenter. Surface and Coatings Technology. 2002;149(1):27-35.

33. Franco AR Jr., Pintaúde G, Sinatora A, Pinedo CE, Tschiptschin AP. The Use of a vickers indenter in depth sensing indentation for measuring elastic modulus and vickers hardness. Materials Research. 2004;7(3):483-491.

34. Rojas JI, Siva BV, Sahoo KL, Crespo D. Viscoelastic behavior of a novel aluminum metal matrix composite and comparison with pure aluminum, aluminum alloys, and a composite made of Al-Mg-Si alloy reinforced with $\mathrm{SiC}$ particles. Journal of Alloys and Compounds. 2018;744:445-452.

35. Carvalho O, Miranda G, Buciumeanu M, Gasik M, Silva FS, Madeira S. High temperature damping behavior and dynamic Young's modulus of AlSi-CNT-SiCp hybrid composite. Composite Structures. 2016;141:155-162.

36. Fecht HJ, Hellstern E, Fu Z, Johnson WL. Nanocrystalline metals prepared by high-energy ball milling. Metallurgical Transactions A. 1990;21:2333-2337. 